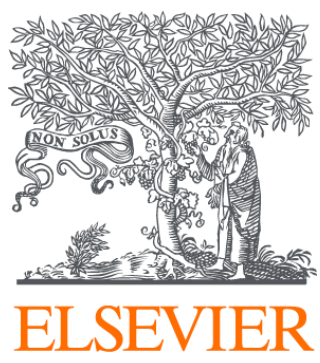

Since January 2020 Elsevier has created a COVID-19 resource centre with free information in English and Mandarin on the novel coronavirus COVID-

19. The COVID-19 resource centre is hosted on Elsevier Connect, the company's public news and information website.

Elsevier hereby grants permission to make all its COVID-19-related research that is available on the COVID-19 resource centre - including this research content - immediately available in PubMed Central and other publicly funded repositories, such as the WHO COVID database with rights for unrestricted research re-use and analyses in any form or by any means with acknowledgement of the original source. These permissions are granted for free by Elsevier for as long as the COVID-19 resource centre remains active. 


\title{
Inactivation of dengue virus by methylene blue/narrow bandwidth light system
}

\author{
Qing Huang, Wei-Ling Fu *, Bing Chen, Jun-Fu Huang, Xue Zhang, Qiang Xue
}

Department of Laboratory Medicine, Southwestern Hospital, The Third Military Medical University, Chongqing, 400038, PR China

Received 18 January 2004; received in revised form 28 May 2004; accepted 12 August 2004

Available online 7 October 2004

\begin{abstract}
Peracetic acid was one of the most commonly used disinfectants on solid surfaces in hospitals or public places. However, peracetic acid is an environmental toxin. Therefore, safer, alternative disinfectants or disinfectant systems should be developed. Because photodynamic virus inactivation with methylene blue (MB)/light system has proven effective in blood banking, MB was selected as a photosensitizing agent, dengue virus as a model virus for enveloped RNA viruses, and an in-house fabricated narrow bandwidth light system overlapping the absorption spectrum of MB as the light source. Dengue virus was mixed with different concentrations of $\mathrm{MB}$, and illuminated by the narrow bandwidth light system under different illumination distances and times. The amount of dengue virus remaining was evaluated by plaque forming assays. Results showed that the concentration of MB working solution, illumination intensity of light source, illumination distance and time were four key factors affecting efficiency of virus inactivation using the $\mathrm{MB} /$ narrow bandwidth light system. Dengue virus could be completely inactivated at $2.5 \mathrm{~m}$ in $5 \mathrm{~min}$ when $\mathrm{MB} \geqslant 1.0 \mu \mathrm{g} / \mathrm{ml}$. However, when the distance reached $3.0 \mathrm{~m}$, only greater concentrations of $\mathrm{MB}(2.0 \mu \mathrm{g} / \mathrm{ml})$ could completely inactivate virus in a reasonably short time $(20 \mathrm{~min})$, and smaller concentrations of $\mathrm{MB}(1.0 \mu \mathrm{g} / \mathrm{ml})$ could only completely inactivate virus using longer times $(25 \mathrm{~min})$. The results of this virus inactivation model indicate that our $\mathrm{MB} /$ narrow bandwidth light system provides a powerful, easy way to inactivate dengue viruses.
\end{abstract}

(C) 2004 Elsevier B.V. All rights reserved.

Keywords: Methylene blue; Photosensitizer; Photodynamic; Virus inactivation; Enveloped RNA viruses

\section{Introduction}

Effective disinfection systems, tools or reagents have been shown to play an important role in the practice of preventing spread of contagious pathogens (e.g., Server Acute Respiratory Syndrome-associated coronavirus). But the use of common disinfectants might result in many by-products with potential genotoxic and/or carcinogenic activity. In a recent study, the micronucleus test in root cells revealed genotoxicity in many 0909.

${ }^{*}$ Corresponding author. Tel.: +86 236546 0802; fax: +86236546

E-mail addresses: qhuang@mail.com (Q. Huang), weilingfu@yahoo.com (W.-L. Fu). samples of water disinfected with sodium hypochlorite, chlorine dioxide, or peracetic acid [1]. In our practice in China, peracetic acid is the most commonly used disinfectant on solid surfaces in hospitals and public places. Because peracetic acid is a stronger oxidizing agent than chlorine or chlorine dioxide, it is much more hazardous for exposure to skin, eyes, the digestive system, or the respiratory system. Moreover, the substance is very toxic to aquatic organisms after environmental disposal without any previous treatment. Therefore, alternative disinfectants or disinfectant systems should be developed that are safer to the environment.

Photodynamic technologies (or photochemical methods) have been proven to be appealing methods for virus inactivation in blood banking applications. In these 
methods, methylene blue (MB) is the most widely used photosensitizing agent for photodynamic inactivation of viruses. MB (MW: 319.85), a member of the group of phenothiazine dyes, was shown to inactivate viruses in human plasma on exposure to light $[2,3]$. Photodynamic treatment with $\mathrm{MB}$, which has a high affinity for enveloped RNA viruses, can effectively inactivate various enveloped RNA viruses, including HIV, hepatitis $B$ virus and hepatitis $C$ virus in plasma, and probably also the non-enveloped parvovirus B19 $[4,5]$.

In the present study, we selected MB as the photosensitizing agent because it is used clinically and because of its known toxicological properties. We fabricated a narrow bandwidth light system consisting of a light-emitting diode (LED) matrix overlapping the maximum absorption wavelength of MB working solution used in this study. Dengue virus, an enveloped RNA virus, served as the model virus in these experiments. Upon photodynamic treatment of dengue virus with the MB/ narrow bandwidth light system, we measured the photodynamic parameters of virus inactivation, and then determined the conditions for effective photodynamic inactivation of dengue virus added to pooled Vero cells.

\section{Materials and methods}

\subsection{Light systems with narrow bandwidth}

Stock aqueous solution of MB $(20 \mathrm{mg} / \mathrm{ml})$ (Jichuan, Inc., Jiangshu, China) was diluted to $10.0 \mu \mathrm{g} / \mathrm{ml}$ in water. One milliliter of $10.0 \mu \mathrm{g} / \mathrm{ml} \mathrm{MB}$ aqueous solution was used to measure its absorption spectrum with a UVspectrophotometer. Light-emitting diodes (LEDs; midpeak bandwidth $29 \mathrm{~nm}$, peak $664 \mathrm{~nm}$ ) with irradiation spectrum overlapping with the maximum absorbing wavelength of MB was used as a light source. The LED matrix was an in-house fabricated light box equipped with $15 \times 19$ (=285) LEDs. The illumination intensity and light color were determined with an ST$80 \mathrm{C}$ radiant power meter (Photo \& Electronic Factory, Beijing, China) and human eyes, respectively.

\subsection{Virus inactivation with the MB/narrow bandwidth light system}

Dengue virus was selected as the model virus for evaluating efficiency of photodynamic inactivation with the $\mathrm{MB} /$ narrow bandwidth light system. Appropriate volumes of stock aqueous solution of MB was added to 1 $\mathrm{ml}$ of $2 \times 10^{6} \mathrm{pfu} / \mathrm{ml}$ dengue virus suspensions in modified Eagle's minimum essential media (EMEM) (ATCC, USA) supplemented with $10 \%$ fetal bovine serum (FBS) to reach final concentrations of $0.1,0.5,1.0$ or $2.0 \mu \mathrm{g} / \mathrm{ml}$ of $\mathrm{MB}$ aqueous solution. The mixture of $\mathrm{MB}$ /virus system was illuminated from above with the narrow band- width light system for $5,10,15,20$ or $25 \mathrm{~min}$ at a distance of $0.5,1.0,1.5,2.0,2.5$ or $3.0 \mathrm{~m}$. After photodynamic inactivation, the virus suspensions were stored at $-80{ }^{\circ} \mathrm{C}$ until used as described in the following sections.

\subsection{Titration of virus by plaque-forming units}

Vero cells were cultured in modified EMEM supplemented with $10 \%$ FBS, glutamine $(0.5 \mathrm{mg} / \mathrm{ml})$, penicillin $(40 \mathrm{IU} / \mathrm{ml})$ and streptomycin $(0.04 \mathrm{mg} / \mathrm{ml})$ at $37^{\circ} \mathrm{C}$ in a humidified atmosphere of $5 \% \mathrm{CO}_{2}$. On the day before infection, Vero cells were incubated in 24-well microtitre plates. On the day of infection, the supernatants of cultured infected cells were discarded and the cells were washed once with EMEM without FBS. Mixtures of $\mathrm{MB} /$ virus illuminated previously with the narrow bandwidth light system were inoculated into the wells of the microtitre plates containing Vero monolayer cells prepared previously. Every mixture corresponding to a different concentration of $\mathrm{MB}$ working solution was inoculated into 10 wells. Inoculums were incubated at $37^{\circ} \mathrm{C}$ for $1 \mathrm{~h}$ with gentle shaking every $10-15 \mathrm{~min}$ to allow adsorption of virus by Vero cells. After 10-min intervals during the adsorption, $1.5 \mathrm{ml}$ of EMEM supplemented with $1 \%$ methylcellulose were added to the inoculums, which were then incubated at $37{ }^{\circ} \mathrm{C}, 5 \%$ $\mathrm{CO}_{2}$ for 6-8 days. The plaques were counted after staining with crystal violet. The titration of dengue virus was assessed with plaque-forming units, and the inactivation effects on dengue virus of different concentrations of $\mathrm{MB}$ solution were evaluated based on the killing log value (KLV). KLV was defined as $\lg N_{0}-\lg N_{x}$, where $N_{0}$ is the initial virus titration $\left(1 \times 10^{7} \mathrm{pfu}\right)$ and $N_{x}$ is the average titration (pfu) for each concentration of MB working solution which has been added to 10 wells [6]. Three controls were set up. A mixture of MB/virus suspension without illumination served as positive control $A$, illuminated virus suspension without $\mathrm{MB}$ served as positive control B, and dilution solution (i.e., modified EMEM supplemented with $2 \%$ FBS) without any virus or MB suspension served as negative control.

\section{Results}

\subsection{Narrow bandwidth light system}

The absorption spectrum of MB was peaked at 664 $\mathrm{nm}$. The LEDs were selected based on peak absorption wavelength of MB and then fabricated into an LED matrix. Emission from this narrow bandwidth light system significantly overlapped the MB absorption spectrum, reducing light penetration through the $\mathrm{MB}$ aqueous solution. On-axis (forward looking) illumination intensity of this narrow bandwidth light system was 5000 
$\mathrm{mlx}$ at a distance of $2.0 \mathrm{~m}$. The emitted color was red as observed by eye.

\subsection{Dynamic parameters of photodynamic inactivation of dengue virus}

Efficiency of virus inactivation of different concentrations of $\mathrm{MB}$ working solution was more than $50 \%$ $(\mathrm{KLV}>3.15)$ at different illumination distances for illu- mination time $>5 \mathrm{~min}$. The results indicate that most of the virus is inactivated in the first 5 min (Fig. 1).

Results of dynamic parameters of inactivation showed that $0.1 \mu \mathrm{g} / \mathrm{ml} \mathrm{MB}$ could not completely kill all virus in any illumination conditions (Fig. 1(a)), and $0.5 \mu \mathrm{g} / \mathrm{ml} \mathrm{MB}$ could only completely kill virus at illumination distance equal to or less than $1.0 \mathrm{~m}$ when illumination time reached $25 \mathrm{~min}$ (Fig. 1(b)). However, when MB concentration was equal to or greater than 1.0
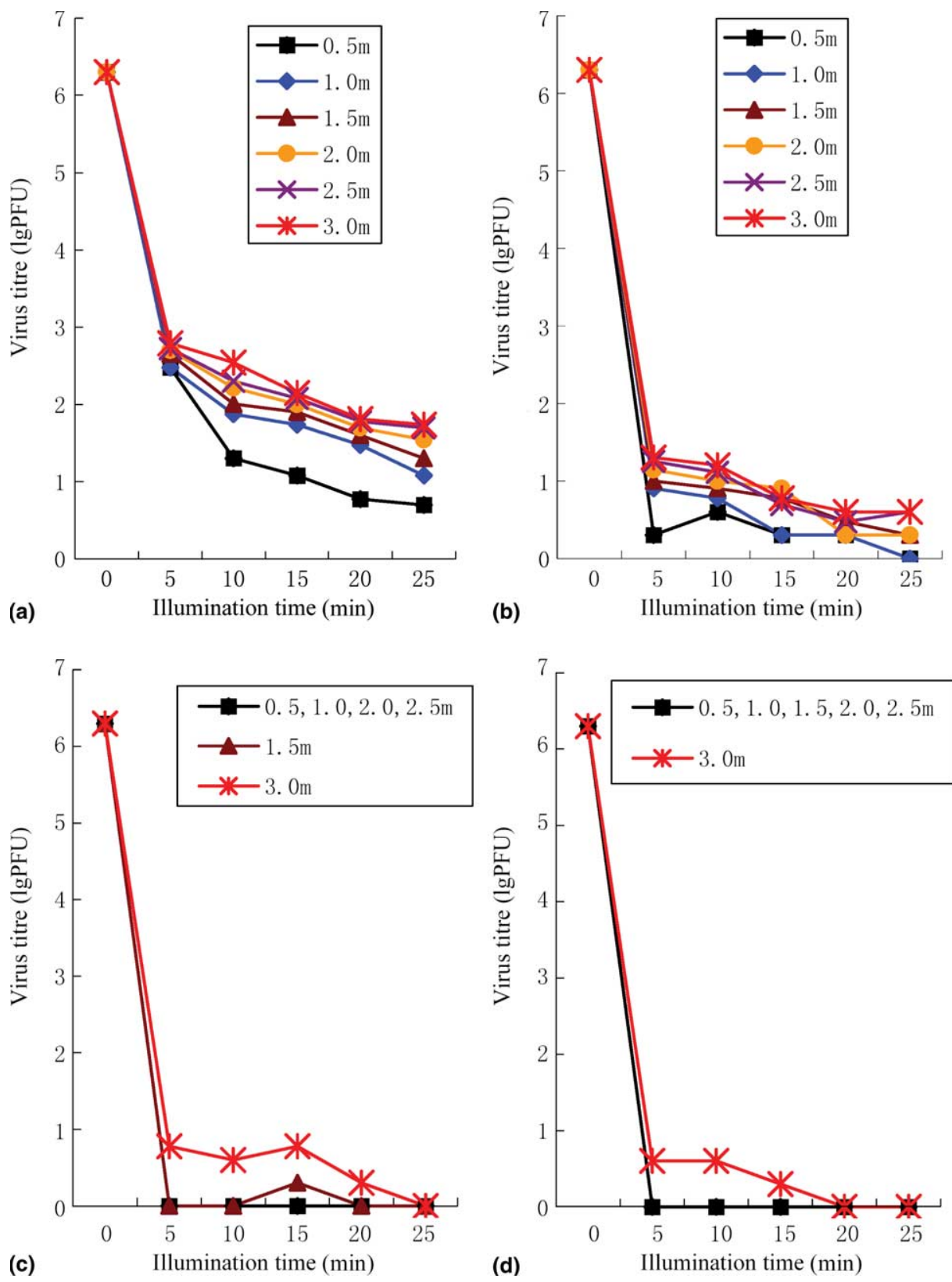

Fig. 1. Photodynamic inactivation of model virus with $\mathrm{MB}$ /narrow bandwidth light system Working concentrations of MB working solution in a, b, $\mathrm{c}$ and $\mathrm{d}$ were $0.1,0.5,1.0$ and $2.0 \mu \mathrm{g} / \mathrm{ml}$ respectively. In $\mathrm{c}$ and $\mathrm{d}$, some of the distance with same inactivation efficiency was combined into one serial in order to give more clear results. The original $\log$ value of model virus (i.e., dengue virus) titre was 6.30 (i.e., $\lg 2 \times 10^{6}$ pfu). Fifty percent $(50 \%)$ of KLV was 3.15 . 
$\mu \mathrm{g} / \mathrm{ml}$, it could completely kill virus at illumination distance equal to or less than $2.5 \mathrm{~m}$ in $5 \mathrm{~min}$ (Fig. 1(c) and (d)). If the distance was as long as $3.0 \mathrm{~m}$, only MB at the highest tested concentration $(2.0 \mu \mathrm{g} / \mathrm{ml})$ could completely kill viruses, and only when illumination time reached $20 \mathrm{~min}$ (Fig. 1(d)). However, lower concentrations $(1.0 \mu \mathrm{g} / \mathrm{ml})$ of $\mathrm{MB}$ could completely kill virus after an extended illumination time (25 min) (Fig. 1(c)). The results indicate that $\mathrm{MB}$ concentration, illumination time and distance are three key factors affecting efficiency of virus inactivation when the illumination intensity of the light source was held constant.

However, because illumination intensity at the target is decreased with distance from the source, our results also indicate that the illumination intensity is the fourth key factor affecting killing efficiency of virus inactivation. Moreover, the results also indicate that equivalent inactivation effects could be achieved at lower concentrations of $\mathrm{MB}$ and at shorter times and longer distances via increasing illumination intensity of the light source.

As a consequence, there were four key factors, which were MB concentration, illumination intensity of light source, illumination time and distance, for our photodynamic virus inactivation instrument. The effects of virus inactivation were increased with the increase of MB concentration, the enhancement of illumination intensity of the light source and the extension of illumination time, as well as the decrease of illumination distance.

\section{Discussion}

Photodynamic antimicrobial agents based on the well-established phenothiazinium biological stain methylene blue offer a simple method for the inactivation of viruses (e.g., HIV, hepatitis C virus and hepatitis B virus) contained in donated blood and blood products or collections. This method has been widely used in the prevention of transfusion-transmitted diseases in the clinic. Moreover, because pathogens of bacterial, yeast and protozoal classes are also susceptible to phenothiaziniums, the $\mathrm{MB} /$ light system has also been used in photodynamic antimicrobial chemotherapy [7]. Chemical and biological properties of MB have been thoroughly studied [8,9]. The optical absorption of MB is optimum for the blood banking application, and it is currently being used clinically for photoinactivation of fresh frozen plasma in Europe [8]. MB/lighttreatment has proved to be the most suitable method of virus inactivation since it provides an acceptable compromise between viral safety and impaired materials (e.g., plasma) quality. MB can bind to and enter via the virus membrane, whereupon it intercalates with nucleic acids. Upon illumination, it then absorbs visible light energy and becomes activated with generation of highly reactive oxygen species (e.g., singlet oxygen).
These disrupt the viral membrane and cause destruction of the nucleic acids, particularly at guanosine residues. The resulting nucleic acid modification can prevent viral replication and induce the inactivation of viruses through both Type I and II pathways [7]. The MB then reverts, in the presence of oxygen, back to its original state.

In traditional photodynamic inactivation of virus, a white light source is commonly used. Because the absorption spectrum of MB solution is between 620 $\mathrm{nm}$ and $700 \mathrm{~nm}$, it is light in this range that shows reaction activity with MB solution. Light of other wavelengths should not inactivate virus with MB molecules. Therefore, if a white light source is used, strong illumination intensity is required. However, a high concentration of MB (e.g., $1 \mu \mathrm{M}$ ) and a short distance (e.g., 20 $\mathrm{cm}$ ) is used in blood banking applications [4]. Because the emission of LEDs is almost monochromatic and can be characterized by a peak wavelength, light energy of an LED light source matching the peak wavelength of the $\mathrm{MB}$ photosensitizing agent can be transmitted to MB molecules in a high efficiency manner. Upon selecting LEDs matching the peak absorption of MB, lower illumination intensity was needed to inactivate virus at longer distance (e.g., present studies). Compared to a final concentration (i.e., $1 \mu \mathrm{M}$ ) which always works at 20 $\mathrm{cm}$ in previous photodynamic inactivation of enveloped RNA viruses in plasma, a much lower concentration of MB $(1.0 \mu \mathrm{g} / \mathrm{ml})$ can completely kill virus at $2.5 \mathrm{~m}$ in 5 min under our custom-designed narrow bandwidth light system. Thus a light source with narrow bandwidth matching the peak absorption of $\mathrm{MB}$ is an appealing technology for inactivation of enveloped RNA viruses. The results indicated that our $\mathrm{MB} /$ narrow bandwidth light system provides a powerful and easy way to inactivate enveloped virus in solution at a longer distance and in a shorter time than with traditional $\mathrm{MB} /$ light systems used in blood banking applications.

In our MB/narrow bandwidth light system, the four factors affecting inactivation efficiency of $\mathrm{MB}$ can be grouped into two types. Type I is the property of MB itself, i.e., its final working concentration. Type II is the feature of the narrow bandwidth light system, which includes the illumination intensity, time and distance. Increase of $\mathrm{MB}$ final concentration and/or illumination intensity enables the narrow bandwidth light system to kill or inactivate enveloped virus at much greater distance in much shorter time. The present studies indicate that the narrow bandwidth light system could be used as an appealing disinfectant tool for inactivation of enveloped virus in environments such as resting or working places where the surfaces were not shaded from the light source. In the European pharmacopoeia, MB is listed as a reagent suitable for external use [10]. High dose of MB (i.e., $2.0 \mathrm{mg} / \mathrm{kg}$ ) has also been studied in the treatment of human septic shock and no adverse effect was observed 
[11]. Animal studies examining high-dose MB have also failed to demonstrate significant toxicity [12]. Therefore, our $\mathrm{MB} / \mathrm{SW}$-light system can be used continuously for a long time without any harm to humans.

\section{Conclusion}

MB working concentration and illumination intensity, time and distance are the four key factors affecting the inactivation efficiency of the $\mathrm{MB} /$ narrow bandwidth light system. Compared to current methods, this $\mathrm{MB} /$ narrow bandwidth light system might be a safer and more effective disinfectant tool for inactivation of enveloped RNA.

\section{Abbreviations}

MB methylene blue

EMEM Eagle's minimum essential media

FBS fetal bovine serum

LEDs light-emitting diodes

KLV killing log value

\section{Acknowledgements}

This study was supported by a grant from the Scientific Technology Foundation of Chongqing, China (Charity No. 6747). The authors are extremely appreciative of Prof. Larry Baum, Department of Medicine and Therapeutics, The Chinese University of Hong Kong, for his revision and review of this paper.

\section{References}

[1] S. Monarca, M. Rizzoni, B. Gustavino, C. Zani, A. Alberti, D. Feretti, I. Zerbini, Genotoxicity of surface water treated with different disinfectants using in situ plant tests, Environ. Mol Mutagen. 41 (2003) 353-359.

[2] B. Lambrecht, H. Mohr, J. Knuver-Hopf, H. Schmitt, Photoinactivation of viruses in human fresh plasma by phenothiazine dyes in combination with visible light, Vox Sang. 60 (1991) 207-213.

[3] H. Mohr, J. Knuver-Hopf, B. Lambrecht, H. Scheidecker, H. Schmitt, No evidence for neoantigens in human plasma after photochemical virus inactivation, Ann. Hematol. 65 (1992) 224 228.

[4] A.M.H.P. van den Besselaar, A.C.E. Moor, Photodynamic treatment of pooled coumarin plasma for external quality assessment of the prothrombin time, J. Clin. Pathol. 53 (2000) 470.

[5] H. Mohr, B. Bachmann, A. Klein-Struckmeier, B. Lambrecht, Virus inactivation of blood products by phenothiazine dyes and light, Photochem. Photobiol. 65 (1997) 441-445.

[6] China Ministry of Health, Technical standard for disinfections. Beijing, China, 2002.

[7] M. Wainwright, Methylene blue derivatives - suitable photoantimicrobials for blood product disinfection?, Int. J. Antimicrob. Agents 16 (2000) 381-394.

[8] S. Jockusch, D. Lee, N.J. Turro, E.F. Leonard, Photo-induced inactivation of viruses: adsorption of methylene blue, thionine, and thiopyronine on Qbeta bacteriophage, Proc. Natl. Acad. Sci. USA 93 (1996) 7446-7451.

[9] E.M. Tuite, J.M. Kelly, Photochemical interactions of methylene blue and analogues with DNA and other biological substrates, J. Photochem. Photobiol. B: Biol. 21 (1993) 103-124.

[10] K. Stamoulis, K. Sofroniadou, Virus inactivation of plasma and its derivatives, Haema 5 (2002) 213-221.

[11] J.C. Preiser, P. Lejeune, A. Roman, E. Carlier, D. De Backer, M. Leeman, R.J. Kahn, J.L. Vincent, Methylene blue administration in septic shock: a clinical trial, Crit. Care Med. 23 (1995) 259-264.

[12] G. Rentsch, D. Wittekind, Methylene blue and erythrocytes in the living animal. Contribution to the toxicology of methylene blue and formation of Heinz bodies, Toxicol. Appl. Pharmacol. 11 (1967) 81-87. 